\title{
PETER ABELARD IN NJEGOVE NESREČE
}

\author{
MATEJA ŠVAJNCER
}

\section{ŽIVLJENJE PETRA ABELARDA}

Peter Abelard se je rodil leta 1079 v Le Palletu, v bližini Nantesa. ${ }^{1}$ V Lochesu se je približno med letoma 1093 in 1099 šolal pri Roscelinu, nato je okoli leta 1100 odšel v Pariz k Viljemu iz Champeauxa. Med letoma 1102 in 1105 je poučeval najprej v Melunu in nato $v$ Corbeilu. Zaradi izčrpanosti se je nato za tri leta vrnil domov. Po okrevanju je odšel nazaj k Viljemu iz Champeauxa in ga izzval glede vprašanja univerzalij. Okoli leta 1112 se je Abelard ponovno odpravil domov, saj sta njegova starša vstopila v samostan. Leta 1113 je odšel k Anzelmu iz Laona, da bi se poučil v teologiji. Po izkušnji z Anzelmom se je okoli 1114 vrnil v Pariz kot učitelj v stolni šoli Notre-Dame. Okoli 1117 je živel v hiši kanonika Fulberta, kjer je zapeljal njegovo nečakinjo Heloizo; približno leto kasneje jo je odpeljal na svoj dom v Le Pallet, kjer je rodila njunega sina Astrolabija. Še istega leta sta se v Parizu poročila; ker so Fulbert in njegovi sorodniki poroko kljub dogovoru o tajnosti razglašali naokrog in grdo ravnali s Heloizo, ki je nato vse zanikala, jo je Abelard poslal v samostan Argenteuil in jo, z izjemo rute, oblekel v redovna oblačila. Fulbertovi sorodniki so se maščevali in Abelarda skopili. Po tem dogodku je Abelard Heloizi ukazal, naj si nadene redovno ruto, sam pa postal menih v Saint Denisu.

Okoli leta 1119 je Abelard nadaljeval svoje poučevanje v opatiji Saint Denis. Leta 1121 so na koncilu v Soissonsu obsodili njegovo knjigo Theologia; še istega leta je pobegnil h grofu Teobaldu v Provins. Leta 1122 se je zatekel v samotarsko bivališče blizu Troyesa in ga posvetil Parakletu. Med letoma 1125 in 1127 se je vrnil v Bretanjo kot opat samostana Saint Gildas; leta 1129 je odšel v Šampanjo in Paraklet prepustil Heloizi in njenim nunam, ki jih je opat Suger pregnal iz Argenteuila. Življenje z menihi iz Saint Gildasa je bilo težavno, po vsem sodeč za obe strani; napetosti so postale tolikšne, da so skušali okoli 1133 menihi Abelarda ubiti.

Še istega leta se je zato vrnil v Pariz kot učitelj na hribu svete Genovefe. Okoli

1 Podatki o Abelardovem življenju in delu so povzeti po knjigi M. T. Clanchyja, Abelard: človek $v$ srednjem veku (Ljubljana: Znanstveno in publicistično središče, 1999). Besedilo je prevedeno po kritični izdaji, ki jo je oskrbel Eric Hicks, izd., La vie et les epistres Pierres Abaelart et Heloys sa fame, Nouvelle bibliothèque du Moyen Âge 19 (Pariz: Champion-Slatkine, 1991), 3-44; v spodnjih opombah okrajšano $\mathrm{s} H \mathrm{HC}$. 
1139 se mu je v cerkvi sv. Hilarija pridružil Arnold iz Brescie. Leta 1141 ga je sveti Bernard na koncilu v Sensu obtožil krivoverstva; ${ }^{2}$ Abelard se je pritožil v Rim, vendar brez uspeha. Zatekel se je v Cluny, kjer ga je zaščitil Peter Častitljivi. Umrl je okoli leta 1142 v clunyjskem samostanu Saint Marcel, v bližini mesta Chalon-sur-Saône.

Veliko Abelardovih del je ohranjenih. Dialectica, delo o logiki, je bila spisana nekje med letoma 1117 in 1121 . Okoli leta 1120 je napisal delo Theologia summi boni, ki vsebuje traktat De unitate et trinitate divina. Predelava te knjige $\mathrm{z}$ naslovom Theologia christiana je nastala med letoma 1121 in 1126 . Tretja različica, z naslovom Theologia scholarium, je nastala med letoma 1132 in 1137. Temeljni predmet Abelardovega dela Theologia je nauk o Trojici. V delu Sic et non, ki je nastalo leta 1121, je zbral stotine navidez protislovnih stališč cerkvenih očetov, da bi se njegovi učenci s premišljevanjem o njih naučili iskanja resnice. Med letoma 1138 in 1139, morda že celo leta 1135, je nastalo njegovo delo Ethica ali Nosce te ipsum.

\section{AVTENTIČNOST TEKSTA HISTORIA CALAMITATUM}

Tekst poznamo iz devetih ohranjenih rokopisov, najstarejši je iz 13. stoletja. ${ }^{3}$ Historia calamitatum vedno nastopa skupaj s sedmimi drugimi Abelardovimi in Heloizinimi pismi, vedno na prvem mestu. Morda ni nobenega zgodnejšega rokopisa prav zato, ker pisma ob svojem nastanku niso prišla v javnost. ${ }^{4}$

Vprašanje avtentičnosti teh pisem je postalo aktualno šele v času, ko se je zgodovina skušala formirati kot znanstvena disciplina. ${ }^{5}$ Med letoma 1913 in 1940 je Bernhard Shmeidler izdal več razprav in v njih dokazoval, da je avtor vseh pisem Abelard in da gre za literarno fikcijo. ${ }^{6}$ Schmeidlerjeve dokaze proti avtentičnosti je zavrnil Etienne Gilson, ki je trdil, da je Heloiza avtorica svojih pisem, Abelard pa

2 Za podrobnejšo razpravo glej Werner Robl, "Das Konzil von Sens 1141 und seine Folgen: Der Ketzerprozess gegen Peter Abaelard im Spiegel der Zeitgeschichte, «ttp://www.abaelard.de/ abaelard/Main.htm.

3 Za podrobnejšo razlago prim. Eric Hicks, ur., La vie et les epistres Pierres Abaelart et Heloys sa fame (Pariz: Champion-Slatkine, 1991), xliv-lii; Jacques Monfrin, ur., Abélard: Historia calamitatum; Texte critique avec une introduction, Bibliothèque des textes philosophiques (Pariz: J. Vrin, 1959), 9-51; J. T. Muckle, »Abelard's Letter of Consolation to a Friend (Historia Calamitatum), "Mediaeval Studies 12 (1950): 163-67.

4 Muckle, »Abelard's Letter of Consolation, « 173.

5 Peter von Moos, Mittelalterforschung und Ideologiekritik: Der Gelehrtenstreit um Héloise (München: Fink, 1974), kot navaja John Marenbon, »Authenticity revisited, « v: Listening to Heloise: The Voice of a Twelfth-Century Woman, ur. Bonnie Wheeler, The New Middle Ages (Basingstoke: Macmillan, 2000), 19.

6 John F. Benton in Fiorella Prosperetti Ercoli, »The Style of the Historia Calamitatum: A Preliminary Test of the Authenticity of the Correspondence Attributed to Abelard and Heloise, «Viator 6 (1975): 59-60. 
svojih. ${ }^{7}$ Omeniti velja, da se je polemika nanašala predvsem na avtorstvo ostalih pisem v zbirki, ne pa na prvo pismo; Historia calamitatum je vedno veljala za pristno.

Pomemben zasuk je povzročil John Benton, ki je trdil, da so vsa pisma ponaredki, in sicer Historia calamitatum iz 12. stoletja, ostala pisma pa iz 13. stoletja. ${ }^{8}$ Muckle in Benton sta imela za nemogoče, da bi lahko srednjeveška nuna na ta način pisala o ljubezni in spolnosti ter tako živela dvojno življenje. ${ }^{9}$ Leta 1980 je Benton od svoje teze odstopil; Historia calamitatum se mu ni več zdela fiktivna, menil pa je, da je Abelard ponaredil Heloizina pisma. ${ }^{10} \mathrm{Na}$ njegovih prvotnih izhodiščih je vztrajal Hubert Silvestre, ki je trdil, da Jean de Meun v 13. stoletju pisem ni le prevedel v francoščino, temveč je ponaredil tudi latinsko besedilo. ${ }^{11}$ Obstajajo tudi modifikacije zgornjih teorij. Ena od novejših zastopa stališče, da je pisma napisal en sam avtor, torej Abelard, vendar pa ne izključuje vloge Heloize; Abelard naj bi povzel le diskusijo, ki je med njima dejansko potekala. ${ }^{12}$

D. W. Robertson je v sedemdesetih letih prejšnjega stoletja videl v celotni korespondenci Abelardovo predstavitev Heloizine poti, torej spreobrnitve od človeške mesenosti k položaju spoštovane opatinje. ${ }^{13}$ Peter von Moos je po drugi strani trdil, da je korespondenca delo obeh, tako Heloize kot Abelarda, in da sta jo sestavila namenoma. Leta 1988 se tudi on začel nagibati k predstavi o enem samem avtorju, še vedno pa je kolebal med tem, ali je to literarno fikcijo ustvaril Abelard ali je šlo za ponarejevalca. ${ }^{14}$ Po eni izmed možnih razlag je korespondenca nastala z namenom zagotoviti ustanovitvene listine za Paraklet; Eileen C. Sweeney sicer poudarja, da takšno stališče Heloizi in Abelardu ne odreka avtorstva. ${ }^{15}$

Zaenkrat torej ni trdnih dokazov proti avtentičnosti teksta; Historia calamitatum zato velja za pristno. Korespondenco med Abelardom in Heloizo pa je moral nekdo kljub temu urediti. Najverjetneje je bila to kar sama Heloiza. ${ }^{16}$

7 Etienne Gilson, Heloise and Abelard, prev. L. K. Shook, 3. izd. (Ann Arbor: The University of Michigan Press, 1968), 145-66.

8 M. T. Clanchy, izd., Pierre Abelard: The Letters of Abelard and Heloise, prev. Betty Radice (Harmondsworth: Penguin Books, 2003), lxvi.

9 Glej J. T. Muckle, »The Personal Letters Between Abelard and Heloise, « Mediaeval Studies 15 (1953): 47-67.

10 Clanchy, Letters of Abelard and Heloise, lxv.

11 Marenbon, »Authenticity revisited, "20-21; Clanchy, Letters of Abelard and Heloise, lxviii.

12 Clanchy, Letters of Abelard and Heloise, lxvi.

13 Peter Dronke, Abelard and Heloise in Medieval Testimonies (Glasgow: The University of Glasgow Press, 1976), 13-14.

14 Marenbon, »Authenticity revisited, «26.

15 Eileen C. Sweeney, "Abelard's Historia Calamitatum and Letters: Self as Search and Struggle," Poetics Today 28, št. 2 (2007): 307, op. 5.

16 Clanchy, Letters of Abelard and Heloise, lxvii, lxx.; Dronke, Abelard and Heloise in Medieval Testimonies, 30-31; C. S. Jaeger, »The Prologue to the Historia calamitatum and the 'Authenticity Question',«Euphorion 74, št. 1 (1980). 


\section{ČAS IN VZROK NASTANKA TEKSTA}

Historia calamitatum je po obliki pismo, razdeljeno na več tematskih sklopov. Pripoved se začne s prologom, kjer Abelard razkrije razloge za nastanek pisma. Prijatelju se je namreč odločil razkriti zgodbo o svojih nesrečah, da bi ta s primerjavo spoznal, kako neznatne so njegove lastne. Abelardovo življenje je torej exemplum, ki naj bi prijatelja pomiril. Poudariti je treba, da ne vemo, kdo naj bi ta prijatelj sploh bil.

Ker Abelard v tekstu ne navaja datumov, točnega nastanka dela ne poznamo. Zdi se, da je delo nastalo okoli leta 1132, ko je Abelard živel v samostanu Saint Gildasde-Ruis v Bretanji. Tja je odšel, ker je menil, da bo tako od sebe vsaj malo odvrnil spletke vseh mogočih zavistnežev. ${ }^{17}$ Toda na lastno žalost je prišel med Christianos atque monachos gentibus longe seviores atque pejores. ${ }^{18}$ Godilo se mu je še slabše kot prej, saj so mu stregli celo po življenju. Svoje občutke opisuje sam; ker ni razumel njihovega jezika, se je v tej deželi počutil kot tujec, nanj pa so pritiskali tako menihi kot mogočen lokalni oblastnik, ki si je njihovo ozemlje podvrgel in ga izkoriščal sebi v prid. Abelard se je imel za obupno osamljenega: „Cum autem terre illius barbaries pariter exlex et indisciplinata esset, nulli erant hominum ad quorum confugere possem adjutorium, cum a moribus omnium pariter dissiderem. $\aleph^{19}$ Ferguson zato razlaga, da prvotna funkcija pisma ni tolažba prijatelja, temveč tolažba samega Abelarda; v okolju, kjer mu je tolažnikov močno primanjkovalo, mu morda ni preostalo drugega, kot da je to funkcijo prevzel kar sam. ${ }^{20}$ To verjetno drži, vendar v luči stališča Mary McLaughlin, ki je menila, da je Abelard pismo namenil širši publiki; bilo naj bi nekakšna apologija. S takšnim zagovorom je skušal Abelard morda vnaprej zavrniti kritike, ki so opozarjali na to, kako neuspešno vodi opatijo Saint Gildas-de-Ruis. Pisanje bi mu torej omogočilo vrnitev v javno udejstvovanje, bodisi v Parakletu ali v pariških šolah. ${ }^{21}$

17 HC 14b1091-97.

18 HC 14b1098-99.

19 HC 14b1135-38.

${ }^{20}$ Chris D. Ferguson, "Autobiography as Therapy: Guibert de Nogent, Peter Abelard, and the Making of Medieval Autobiography, « Journal of Medieval and Renaissance Studies 13, št. 2 (1983): 201.

21 Mary M. McLaughlin, »Abelard as Autobiographer: The Motives and Meaning of His Story of Calamities, Speculum 42, št. 3 (1967): 468. 